\title{
A MALE PIG WITH AN XXY/XXXY SEX CHROMOSOME COMPLEMENT
}

\author{
M. J. A. HARVEY \\ Department of Veterinary Reproduction, University of Glasgow Veterinary Hospital, \\ Bearsden, Glasgow
}

(Received 23rd November 1967)

\begin{abstract}
Summary. A male pig, suffering from lymphosarcoma, was found to have a genotype $39, \mathrm{XXY} / 40, \mathrm{XXXY}$, by the use of peripheral blood culture and sex chromatin studies. This is compared to Klinefelter's syndrome and certain aspects of this condition are briefly discussed, together with the co-existence of the chromosome aberration and the neoplasia.
\end{abstract}

\section{INTRODUCTION}

All breeds of the domestic pig (Sus scrofa) studied by recent techniques have been found to have a diploid chromosome number of 38 (Ruddle, 1961; McConnell, Fechheimer \& Gilmore, 1963). The European wild pig, however, can have either 36 or 37 chromosomes (McFee, Banner \& Rary, 1966). These authors postulated that if the domestic pig is derived from the wild pig with 36 chromosomes, centric splitting of a submetacentric chromosome pair of the wild species has produced two extra acrocentric pairs in the domestic pig. They further suggested that the introduction of domestic stock may have resulted in the development of animals with an odd number of chromosomes, which are fertile because apparently no chromatin material has been lost.

By analogy with other species, including man, domestic pigs with various developmental abnormalities would be expected to show occasional numerical and structural abnormalities in chromosome complement. So far, in the pig, only two types of chromosome aberrations have been found. Henricson \& Bäckström (1964) found an autosomal translocation in a boar with reduced fertility and McFee, Knight \& Banner (1966) found sex chromosome mosaicism, $38, \mathrm{XX} / 38, \mathrm{XY}$, in a male pseudohermaphrodite pig. All other intersexes in this species have had a normal female chromosome constitution, despite varying degrees of masculinization of the genital tract (Cantwell, Johnston \& Zeller, 1958; Hard \& Eisen, 1965; Vogt, 1966; Gerneke, 1967).

This report describes a pig with a chromosome mosaicism-39,XXY/ $40, \mathrm{XXXY}$, discovered during an investigation into the chromosomal findings in various pathological conditions affecting the domestic pig. 


\section{MATERIALS AND METHODS}

The animal was a 10-month-old castrated male Large White. It was under observation because of suspected lymphosarcoma, the main clinical features being a high fluctuating white cell count and a very poor growth rate. One litter mate had died of lymphosarcoma, but the rest of the litter of eight all had good weight gains and normal white cell counts. The decision to carry out chromosome analysis was prompted by studies in the dog (Basrur \& Gilman, 1966) and the cow (Basrur, Gilman \& McSherry, 1964) which showed chromosome aberrations in association with lymphosarcoma.

Peripheral blood culture was carried out by a method modified from Moorehead, Nowell, Mellman, Battips \& Hungerford (1960). Venous blood (20 ml) was collected aseptically from the anterior vena cava, thoroughly mixed with $1 \mathrm{ml}$ heparin (1000 units/ml, Boots Pure Drug Co.) in a 1-oz sterile Universal bottle and packed in ice until ready for processing. In the laboratory, $1 \mathrm{ml}$ of reconstituted phytohaemagglutinin (Burroughs Wellcome \& Co.) was added to the blood which was kept at $4^{\circ} \mathrm{C}$ for $1 \mathrm{hr}$ to allow partial sedimentation of the red blood cells. It was then centrifuged for $5 \mathrm{~min}$ at $750 \mathrm{rev} / \mathrm{min}$ and the supernatant plasma and buffy coat drawn off. The remaining blood was spun at $1500 \mathrm{rev} / \mathrm{min}$ for $15 \mathrm{~min}$ to give a cell-free plasma layer.

$0.8 \mathrm{ml}$ of white cell suspension and $1.2 \mathrm{ml}$ of cell-free plasma were added to $8 \mathrm{ml} \mathrm{T.C.} 199$ (Glaxo) and $0.2 \mathrm{ml}$ phytohaemagglutinin in 1-oz Universal bottles, to give a final white cell count of 0.9 million $/ \mathrm{ml}$ culture medium and a plasma concentration of $20 \%$. After $71 \mathrm{hr}$ of incubation at $37^{\circ} \mathrm{C}, 1.5 \mu \mathrm{g}$ Colcemid (Ciba) was added per $\mathrm{ml}$ of culture medium and the incubation continued for a further $3 \mathrm{hr}$. The cultures were then transferred to pre-warmed $10-\mathrm{ml}$ centrifuge tubes and subjected to hypotonic treatment with $0.7 \%$ sodium citrate for $30 \mathrm{~min}$ before being fixed with 1:3 glacial acetic acid: absolute alcohol.

A few drops of concentrated cell suspension were dropped on to watercleaned, grease-free slides and air-dried according to the method of Rothfels \& Siminovitch (1958), stained with $2 \%$ aceto-orcein and permanently mounted with $\mathrm{DePeX}$. The slides were scanned under low power, suitable metaphase spreads counted, photographed at $625 \times$ using $35 \mathrm{~mm}$ film, and enlarged to give a final print magnification of $3000 \times$. Karyotypes were arranged according to the general recommendation for human chromosomes set out in the Denver Report (1960).

\section{RESULTS}

\section{Chromosome analysis}

Only one blood culture was possible as the animal died before further tests could be carried out. The results of the culture are set out in Table 1. Seventeen cells containing 39 chromosomes were analysed from photomicrographs and, of these, fifteen showed consistently the presence of an extra chromosome which was morphologically indistinguishable from the $\mathrm{X}$ chromosome (Plate 1). Only two cells containing 40 chromosomes were of a sufficient quality to be 
PLATE 1

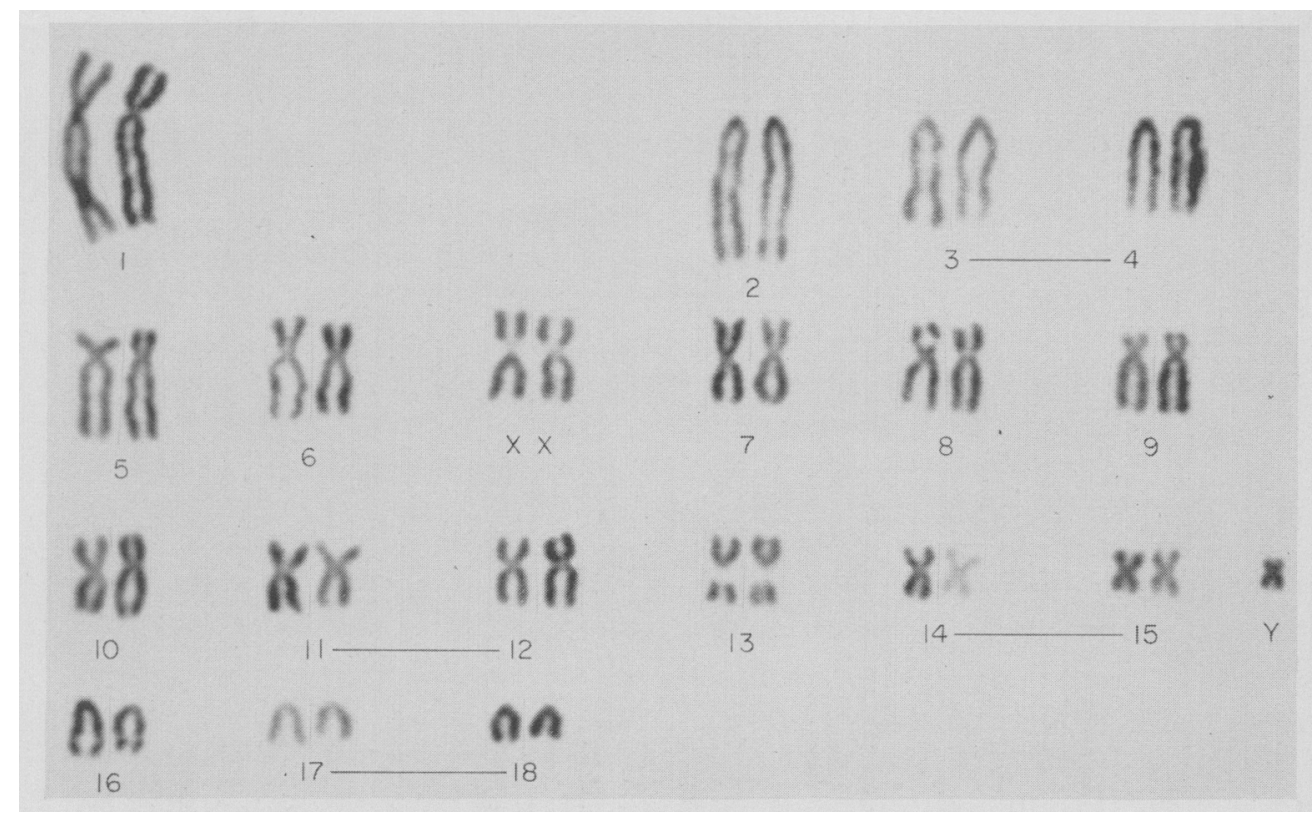

Karyotype of metaphase spread from peripheral blood culture showing XXY sex chromosome complement and eighteen pairs of autosomes. $\times 1700$. 


\section{PLATE 2}

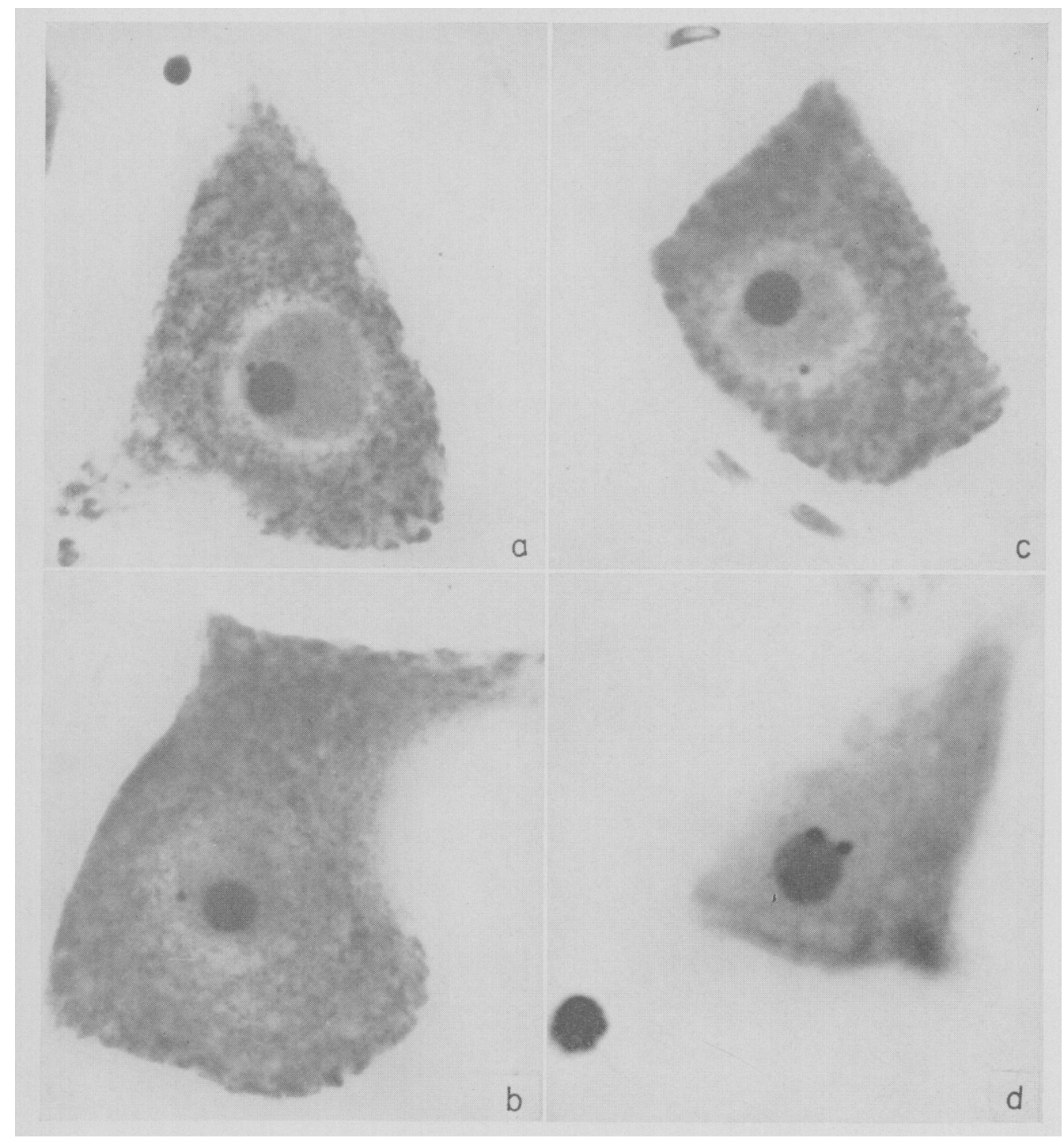

Neurones from an XXY/XXXY pig showing sex chromatin body. (a)-(c) Cells containing single body. $\times 1300$. (d) Cell containing two bodies. $\times 2100$. 
TABLE 1

GHROMOSOME DISTRIBUTION IN LEUCOCYTE GULTURE CELLS FROM FIVE NORMAL PIGS AND AN ABNORMAL PIG

\begin{tabular}{l|c|c|c|c|c|c|c|c}
\hline & \multicolumn{7}{|c|}{ No. of chromosomes per cell } & $\begin{array}{c}\text { Total no. } \\
\text { of cells } \\
\text { examined }\end{array}$ \\
\cline { 2 - 8 } & $<36$ & 36 & 37 & 38 & 39 & 40 & 40 & 581 \\
\hline $\begin{array}{l}\text { \% of cells examined } \\
\text { in five normal pigs }\end{array}$ & 0.34 & 1.03 & 4.13 & 88.82 & 4.13 & 0.69 & 0.86 & 581 \\
$\begin{array}{l}\text { \% of cells examined } \\
\text { in an XXY/XXXY } \\
\text { male }\end{array}$ & 0.58 & 1.74 & 2.33 & 6.40 & 69.77 & 17.44 & 1.74 & 172 \\
\hline
\end{tabular}

analysed and these showed no constant picture. The $\mathrm{Y}$ chromosome was present in every cell analysed.

Sex chromatin analysis

In the pig, only nerve cells are suitable for sex chromatin examination because the nuclei of other tissues contain numerous clumps of coarse chromatin which can easily be confused with the sex chromatin body (Cantwell et al., 1958). Spinal cord is used routinely for sex chromatin examination in this laboratory. The sex chromatin body in the female pig is a small deeply staining body which is characteristically in one of three positions: (1) on the nucleolar membrane, (2) in the nucleoplasm, and (3) on the nuclear membrane (Plate 2).

TABLE 2

SEX CHROMATIN DISTRIBUTION IN NEURONES FROM NORMAL PIGS AND AN ABNORMAL PIG

\begin{tabular}{l|c|r|r|c}
\hline & \multicolumn{3}{|c|}{$\begin{array}{c}\text { No. of sex chromatin } \\
\text { bodies per cell }\end{array}$} & $\begin{array}{c}\text { Total no. } \\
\text { of cells } \\
\text { examined }\end{array}$ \\
\cline { 2 - 5 } & 0 & 1 & 2 & \\
\hline$\%$ cells examined in three normal females & $18 \cdot 33$ & 81.67 & 0.00 & 551 \\
$\%$ cells examined in three normal males & 93.67 & 6.33 & 0.00 & 300 \\
$\%$ cells examined in an XXY/XXXY male & 24.67 & 69.33 & 6.00 & 150 \\
\hline
\end{tabular}

In the present case, immediately after death, 1-cm-long portions of the spinal cord were removed from the animal and fixed in $5 \%$ formol saline for 2 to 3 days. The tissues were processed, embedded in wax, cut at $8 \mu$ and stained with $1 \%$ Cresyl Violet.

Table 2 shows the results of sex chromatin examination in normal males and females and in the pig under examination. A chromocentre indistinguishable from the sex chromatin body is seen in $6.3 \%$ of normal male cells. This body is probably an artifact, as present evidence indicates that a cell containing a single $\mathrm{X}$ chromosome is non-viable if that chromosome is inactivated. The results 
of the sex chromatin counts confirm that the chromosome constitution of the cells from the blood culture is representative of the animal's true genotype and not of the abnormal products of the lymphosarcoma. It would appear that as a proportion of the neurones examined had two sex chromatin bodies present, the cells containing 40 chromosomes were XXXY cells. The most likely interpretation, therefore, is that the animal is a sex chromosome mosaic; one cell line having a $39, \mathrm{XXY}$ complement and the other a $40, \mathrm{XXXY}$ complement.

\section{Autopsy report}

The autopsy revealed that the pig had lymphosarcoma with very widespread metastases to liver, spleen, kidneys and internal lymph-nodes. Histology of these organs revealed the presence of gross lymphocytic and abnormal cellform infiltration. Histology was not carried out on the genital tract, but the tract did not appear abnormal on macroscopic examination.

\section{DISGUSSION}

The chromosome aberration in the pig is the same as that seen in the sex chromatin positive Klinefelter's syndrome in human males. This aberration has been demonstrated in only one species of domestic animal. Thuline \& Norby (1961) examined twelve male cats with the unusual tortoiseshell coat markings and found two to be sex chromatin positive. Both had 39 chromosomes, one more than the modal number for the species and these were considered to be $\mathrm{XXY}$ individuals. In one case, no gonadal tissue was present and in the other meiosis was seen, but no spermatids nor spermatozoa were present. McFeely, Hare \& Biggers (unpublished) reported a sex chromosome mosaic 38,XY/ $39, \mathrm{XXY}$ in a tortoiseshell male cat which was also infertile. This case had a few spermatogonia and an occasional spermatid in the testes, but no spermatozoa were found in the epididymides. This indicates that in the cat, as in the mouse (Russell \& Chu, 1961) and man (Ferguson-Smith, 1959), the presence of additional $\mathrm{X}$ chromosomes has some effect on gonadal development and subsequent function, all reported cases having been sterile.

The hypothesis that one of the two $\mathrm{X}$ chromosomes in the normal female is genetically inactivated, forming the sex chromatin body, was first put forward by Lyon (1961). On the evidence of human individuals with supernumerary $\mathrm{X}$ chromosomes, the extension of the hypothesis was that, whatever the number of $\mathrm{X}$ chromosomes present, only one remains active (Lyon, 1962). On the evidence of the present case, the Lyon hypothesis appears to be valid in the pig, as the sex chromatin results can be correlated with the presence of the extra $\mathrm{X}$ chromosomes. The fact that testes were present indicates that in this species also, the $\mathrm{Y}$ chromosome is male-determining in the presence of two $\mathrm{X}$ chromosomes. Macroscopic examination of the testes in cases of men with Klinefelter's syndrome does not reveal any obvious abnormalities before puberty and this appears to parallel the findings of the present case. However, in the human case, biopsy examination of the testes before puberty has demonstrated 
a marked deficiency or even complete absence of spermatogonia (FergusonSmith, 1959). XXY patients are often mentally handicapped, and the fact that physical and mental disabilities increase in proportion to the number of additional $\mathrm{X}$ chromosomes seems to contradict the Lyon hypothesis, which at first postulated that inactivation involves all the genes on one $\mathrm{X}$ chromosome. Russell (1963) showed that complete inactivation does not occur in the mouse $\mathrm{X}$ chromosome and it seems possible that XXY individuals of mammals in general may have an abnormal dosage of some sex-linked genes. FergusonSmith and his co-workers (1964) concluded from a study of Turner's syndrome in the human subject that part of the inactivated $\mathrm{X}$ chromosome is not in fact inactivated and that with this slight modification, the Lyon hypothesis is still valid.

The co-existence of lymphosarcoma and the sex chromosome aberration in this case raises the question of whether the latter may predispose to the former. In man some evidence exists in support of this theory. Borges, Nicklas \& Hamm (1967) examined twenty-five non-mongoloid children with acute leukaemia and found that four had cytogenetic abnormalities, two of which were of the chromosomal complement, 47,XXY. These workers postulated that aneuploid cells are more susceptible to post-zygotic environmental factors which may eventuate in acute leukaemia.

A study of a selected series of sterile boars is envisaged, in the hope that other $\mathrm{XXY}$ individuals may be found in which the effect of extra $\mathrm{X}$ chromosomes on the phenotype and the possible co-existence of neoplasia may be further explored.

\section{ACKNOWLEDGMENTS}

This work was carried out under Grant No. 1557 from the Pig Industry Development Authority.

The author wishes to thank Mr H. S. McTaggart and Mr K. W. Head of the Royal (Dick) School of Veterinary Studies, Edinburgh, for giving access to the animal used in this study, for their kind assistance in providing samples and for carrying out the autopsy. Thanks are also due to Mr R. D. McLaren and Miss C. Quirk for technical assistance in the sex chromatin studies, and to Dr M. A. Ferguson-Smith of the Department of Genetics, University of Glasgow, and Mr P. G. Hignett of the Department of Reproduction, Glasgow University Veterinary Hospital, for much helpful discussion and encouragement.

\section{REFERENCES}

Basrur, P. K. \& Grlman, J. P. W. (1966) Chromosome studies in canine lymphosarcoma. Cornell Vet. 56,451 .

Basrur, P. K., Gilman, J. P. W. \& McSherry, B. J. (1964) Cytological observations on a bovine lymphosarcoma. Nature, Lond. 201, 368.

Borges, W. H., Nicklas, J. W. \& Hamm, C. W. (1967) Prezygotic determinants in acute leukaemia. 7. Pediat. 70, 180.

Gantwell, G. E., Johnston, E. F. \& Zeller, J. H. (1958) The sex chromatin of swine intersexes. 7. Hered. 49, 199.

Denver Report (1960) A proposed standard system of nomenclature of human mitotic chromosomes. Lancet, i, 1063. 
FERguson-Sмтth, M. A. (1959) The pre-pubertal testicular lesion in chromatin-positive Klinefelter's syndrome (Primary micro-orchidism) as seen in mentally handicapped children. Lancet, ii, 880.

Ferguson-Smith, M. A., Alexander, D. S., Bowen, P., Goodman, R. M., Kaufman, B. N., Jones, H. W., JR \& Heller, R. H. (1964) Clinical and cytogenetic studies in female gonadal dysgenesis and their bearing on the cause of Turner's Syndrome. Cytogenetics, 3, 355.

Gerneke, W. H. (1967) Cytogenetic investigations on normal and malformed animals, with special reference to intersexes. Onderstepoort F. vet. Res. 37, 219.

HARD, W. L. \& EISEN, J. D. (1965) A phenotypic male swine with a female karyotype. F. Hered. 56, 255.

Henricson, B. \& BÄcksTröm, L. (1964) Translocation heterozygosity in a boar. Hereditas, 52, 116.

Lyon, M. F. (1961) Gene action in the $\mathrm{X}$ chromosome of the mouse (Mus. musculus L.). Nature, Lond. $190,372$.

Lyon, M. F. (1962) Sex chromatin and gene action in the mammalian X chromosome. Am. 7. hum. Genet. 14, 135.

McConnell, J., Fechheimer, N. S. \& Gilmore, L. O. (1963) Somatic chromosomes of the domestic pig. F. Anim. Sci. 22, 374.

McFee, A. F., BANner, M. W. \& RARY, J. M. (1966) Variation in chromosome numbers among European wild pig. Cytogenetics, $5,75$.

MaFeE, A. F., KNIGHT, M. \& BANNER, M. W. (1966) An intersex pig with XX/XY leucocyte mosaicism. Can. F. Genet. Cytol. 8, 502.

Moorehead, P. S., Nowell, P. C., Mellman, J., Battips, D. M. \& Hungerford, D. A. (1960) Chromosome preparations of leucocytes cultured from human peripheral blood. Expl Cell Res. 20, 613 .

Rothfels, K. H. \& Siminovitch, L. (1958) An air-drying technique for flattening chromosomes in mammalian cells grown in vitro. Stain Technol. 33, 73.

Ruddle, F. H. (1961) Chromosome variation in cell population derived from pig kidney. Cancer Res. $21,885$.

Russelt, L. B. (1963) Mammalian X chromosome action; inactivation limited in spread and in region of origin. Science, $\mathcal{N} . Y .140,976$.

Russell, L. B. \& GHU, E. H. Y. (1961) An XXY male in the mouse. Proc. natn. Acad. Sci. U.S.A. 47, 571.

Thuline, H. G. \& Norby, D. E. (1961) Spontaneous occurrence of chromosome abnormalities in cats. Science, N.Y. 134, 554.

VoGt, D. W. (1966) Cytological observations on an intersex pig. F. Anim. Sci. 25, 252. 